JURNAL RESPIRASI

$J R$

Vol. 1 No. 3 September 2015

\title{
Farmakogenomik Hepatotoksisitas Obat Anti Tuberkulosis
}

\author{
Andri Dwi Wahyudi, Soedarsono \\ Departemen Pulmonologi dan Ilmu Kedokteran Respirasi, Fakultas Kedokteran Universitas Airlangga/RSUD Dr. Soetomo
}

\begin{abstract}
Anti-TB drugs (ATD) associated with hepatotoxicity is a serious medical problem in the world, especially for patients with TB. The production and expenditures toxic drug metabolites depends on the activity of some enzymes, such as N-acetyl transferase 2 (NAT2), Cytochrome P450 oxidase (CYP2E1) and Glutathione S-transferase (GSTM1). Variations from the DNA sequence or polymorphism at this locus (NAT2, CYP2E1 and GSTM1) can modulate enzyme activity and can affect the risk of hepatotoxicity. Hepatotoxicity is generally unpredictable and occur in a small number of patients even when the drug was given according to the recommended dosage. Among the ATD, the metabolism of INH, which is one of the ATD forefront, has been studied extensively, and said acetylation by NAT2, oxidation by cytochrome P450 oxidase (CYP2E1) and detoxified by GST play an important role in the INH-induced hepatotoxicity. Since the prevalence of polymorphisms is different in worldwide populations, the risk of ATD hepatotoxicity varies in the populations. Thus, the knowledge of polymorphisms at these loci, prior to medication, may be useful in evaluating risk and controlling ATD hepatotoxicity.
\end{abstract}

Key words: pharmacogenomics, hepatotoxicity, ATD, tuberculosis

Correspondence: Andri Dwi Wahyudi, Departemen Pulmonologi dan Ilmu Kedokteran Respirasi, Fakultas Kedokteran Universitas Airlangga/RSUD Dr. Soetomo. Jl. Mayjen. Prof. Dr. Moestopo 6-8 Surabaya 60286. E-mail: ad.wahyudi@ gmail.com

\section{PENDAHULUAN}

Obat anti-TB (OAT) yang berhubungan dengan hepatotoksisitas adalah masalah medis serius di dunia terutama untuk pasien TB. Produksi dan pengeluaran racun metabolit obat tergantung pada aktivitas beberapa enzim, seperti $\mathrm{N}$-asetil transferase 2 (NAT2), sitokrom P450 oksidase (CYP2E1) dan glutathione S-transferase (GSTM1). Variasi dari urutan DNA atau polimorfisme pada lokus ini (NAT2, CYP2E1 dan GSTM1) dapat memodulasi aktivitas enzim ini dan dapat mempengaruhi risiko terjadinya hepatotoksisitas. Pengetahuan polimorfisme pada lokus ini terutama sebelum pengobatan, berguna dalam mengevaluasi risiko dan mengendalikan hepatotoksisitas oleh karena OAT. ${ }^{1}$

Sekitar 9 juta kasus baru aktif TB dilaporkan dan diperkirakan 1,7 juta orang meninggal karena penyakit ini. Saat ini, kombinasi isoniazid (INH), rifampisin (RMP), pyrazinamide (PZA) dan etambutol (E) digunakan untuk terapi TB pada banyak populasi. Awalnya (dalam tahun 1950-an) INH dianggap aman tanpa efek samping, tetapi pada awal 1970-an beberapa penelitian dengan jumlah sampel besar menyatakan bahwa INH ternyata menginduksi terjadinya hepatotoksisitas. Frekuensi dari dampak yang terjadi bervariasi pada setiap populasi: sekitar 1-30 dalam 100 individu dengan pengobatan INH dan RMP. ${ }^{1}$ Hepatotoksisitas ini umumnya tidak terprediksi dan terjadi pada sejumlah kecil pasien bahkan ketika obat telah diberikan sesuai dosis yang dianjurkan. Efek samping ini tidak hanya menyebabkan morbiditas dan mortalitas, tetapi juga menyebabkan terganggunya pengobatan karena ketidakpatuhan, kegagalan dan kekambuhan, yang menyebabkan terus menyebarnya penyakit dan timbulnya resistensi terhadap obat TB. Di antara obat anti-TB (OAT), metabolisme INH, yang merupakan salah satu OAT terdepan, telah dipelajari secara ekstensif, dan dikatakan asetilasi oleh NAT2, oksidasi oleh sitokrom P450 oksidase (CYP2E1) dan detoksifikasi oleh GST memainkan peran penting dalam INH-induced hepatotoksisitas. Metabolit yang dihasilkan oleh NAT2 biasanya tidak beracun. Namun, dalam beberapa kasus, reaksi dimediasi CYP2E1 dapat menyebabkan pembentukan metabolit reaktif beracun yang akan dikeluarkan dari tubuh oleh GST. Metabolit reaktif dapat merusak hepatosit baik dengan mengganggu 
homeostasis sel atau dengan memicu reaksi kekebalan di mana metabolit reaktif, terikat pada protein membran hepatosit plasma, dapat bertindak sebagai haptens. ${ }^{2}$

Polimorfisme pada lokus metabolisme obat yang berbeda dapat menyebabkan perbedaan dalam respon farmakologi terhadap obat pada setiap individu. Farmakogenetik dan $\mathrm{N}$-asetiltransferase secara historis terkait, dan variasi in vivo dalam aktifitas NAT adalah salah satu sifat farmakogenetik yang dikenali paling awal. Aksi dari enzim NAT2 pertama kali diidentifikasi sebagai langkah lanjut yang secara umum dikontrol untuk metabolisme INH. ${ }^{3}$ Pada tahun 1960, pasien TB secara rutin diberikan INH dan terjadinya neuropati perifer diamati pada beberapa pasien. Hal ini dijelaskan oleh lambatnya pembersihan senyawa beracun yang tidak seperti biasanya, asetil hidrazin, dari pasien yang terkena, dan mereka disebut sebagai asetilator lambat. ${ }^{4}$ Namun, beberapa penelitian juga melaporkan bahwa Asetilator cepat NAT2 juga rentan terhadap hepatotoksisitas OAT. ${ }^{5}$ Sebelumnya, NAT2 acetilasi fenotipe ditentukan oleh metode enzimatik, dan beberapa studi mengenai phenotypic sebelumnya telah menyarankan seperti adanya predisposisi meskipun penelitian lain gagal untuk mendukung observasi ini. Individu dibagi ke dalam populasi etnis yang memiliki fenotipe asetilator lambat, menengah atau cepat atas dasar kapasitas asetilasi enzim NAT2. Kebanyakan ras kaukasoid dan minoritas wilayah Asia Tenggara diobservasi sebagai asetilator lambat. ${ }^{4}$ Saat ini diusulkan bahwa tidak hanya NAT2 yang enzim, tetapi juga beberapa enzim lain (seperti CYP2E1 dan GSTM1) dilibatkan dalam hepatotoksisitas OAT, menampilkan polimorfisme genetik, dan prevalensi dari banyaknya populasi dengan variasi polimorfik alleles di seluruh dunia.

Terdapat beberapa perbedaan definisi hepatotoksisitas oleh karena OAT seperti: peningkatan (2-3 kali batas atas nilai normal) aktivitas transaminase, gejala klinis hepatitis, adanya ikterus. Berdasarkan pertemuan international konsensus di Paris tentang pengaruh obat pada gangguan hati, parameter biokimia hati meningkat lebih dari dua kali dari batas normal dianggap sebagai hepatotoksisitas. ${ }^{6}$ Sekitar $10-20 \%$ dari pasien TB mengalami peningkatan serum transaminase tanpa gejala klinik pada pemberian OAT akan menghilang sendiri setelah beberapa minggu.

Dalam tinjauan kepustakaan ini membahas faktor risiko TB, efek hepatotoksik dari OAT, kemungkinan mekanisme toksisitas dan kerentanan dari faktor host genetic. Terutama ditekankan mengenai bagaimana hepatotoksisitas oleh karena OAT dijelaskan oleh adanya alel polimorfik dari faktor genetic host pada populasi.

\section{Epidemiologi}

Perkembangan dunia kedokteran antara lain diwarnai dengan makin banyaknya jenis obat, meningkatkan harapan kesembuhan dari berbagai penyakit. Akan tetapi, perkembangan ini juga membawa dampak tersendiri, seperti makin meningkatnya risiko dan angka kejadian efek samping obat. ${ }^{1,2}$ Meskipun efek samping obat dapat terjadi pada semua sistem organ tubuh, hati merupakan organ yang paling rentan karena sebagian besar obat menjalani metabolisme parsial maupun komplet serta eliminasi melalui hati. Berbagai survei di dunia menunjukkan bahwa frekuensi kerusakan hati yang diinduksi oleh obat sebagai penyebab penyakit hati akut maupun kronik relatif rendah. $^{3,4,5}$ Insidens hepatotoksisitas imbas obat secara umum dilaporkan sebesar 1:10.000 sampai 1:100.000 pasien. $^{7}$ Frekuensi dari dampak yang terjadi bervariasi pada setiap populasi: sekitar 1-30 dalam 100 individu dengan pengobatan INH dan RMP. ${ }^{1}$ Meskipun demikian, insidens hepatotoksisitas imbas obat yang sebenarnya sulit diketahui. Jumlah aktual dapat jauh lebih besar karena sistem pelaporan yang belum memadai, kesulitan mendeteksi atau mendiagnosis, dan kurangnya observasi terhadap pasien-pasien yang mengalami hepatotoksisitas imbas obat. ${ }^{8}$

Secara keseluruhan Frekuensi dari hepatotoksisitas dipengaruhi oleh INH menunjukkan 1-30\% pada populasi yang berbeda, tapi ada yang mencolok terkait usia. Dilaporkan bahwa terjadinya kerusakan hati jarang terjadi pada anak-anak usia di bawah 20 tahun, 1-2\% pada kelompok setengah baya dan 2-3\% pada mereka yang berusia 50 tahun atau lebih. ${ }^{9}$ Tingginya insiden hepatitis imbas OAT juga telah telah dilaporkan pada pasien dengan malnutrisi, penyalahgunaan alkohol, dan pembawa virus hepatitis B dan C serta HIV. ${ }^{10}$ Sebagian besar OAT, misalnya, INH, RMP dan PZA, adalah hepatotoksik. INH, PZA juga dapat menyebabkan kerusakan hati dalam $15 \%$ dari penerima, dan ikterus terjadi pada 2-3\% dari pasien yang mengalami kerusakan hati. INH, menunjukkan hubungan dengan pemberian dosis yang berdampak terhadap hati. Biasanya RMP adalah agen dengan toksisitas rendah, tetapi dapat mengganggu clearance bilirubin dan asam empedu, sehingga menyebabkan intoleransi gastrointestinal. Dalam kasus yang jarang terjadi, juga menyebabkan hepatitis. Etambutol sendiri memiliki efek samping pada penglihatan, tingkat asam urat serum, nyeri sendi dan sebagainya. Mereka juga mungkin memiliki efek sinergis pada fungsi hati pada pasien yang dikombinasikan dengan INH. Kombinasi INH dan RMP, serta INH dan PZA meningkatkan hepatotoksisitas. Dalam studi lain dilaporkan bahwa angka kejadian hepatitis secara klinis adalah 5-8\% dari pasien yang diobati dengan INH dan RMP dibandingkan dengan $1 \%$ pada mereka yang hanya menerima INH. Namun, tidak semua studi menyatakan bahwa pengobatan yang dikombinasikan dengan RMP meningkatkan kejadian hepatitis imbas OAT. ${ }^{11}$

\section{Gejala Klinis dan Pencegahan}

Gejala klinis disebabkan OAT dapat muncul dalam waktu 4 minggu setelah memulai pengobatan. ${ }^{12}$ Sekitar $10 \%$ dari pasien dengan hepatotoksik hanya menderita ikterus saja. Sisanya menunjukkan keluhan terutama pencernaan seperti: anoreksia, mual, muntah dan sakit perut. Dalam sebagian besar kasus, serum alanin transaminase (ALT), aspartat transaminase (AST), alkaline phosphatase (AP) dan bilirubin meningkat lebih dari tiga kali lipat dari 
angka normal, yang juga berdampak pada kerusakan hati. Pasien dengan hepatitis imbas OAT memiliki angka kematian sekitar $10 \%$. Faktor yang paling sering dikaitkan dengan kejadian fatal seperti usia lebih dari 50 tahun dan terus menggunakan obat untuk beberapa minggu setelah timbulnya gejala. ${ }^{13}$ ALT dan bilirubin, merupakan marker yang menandakan kerusakan hati, biasanya kembali normal atau mendekati nilai normal setelah minggu kedua/ ketiga setelah penghentian obat. Penting untuk mencegah hepatitis imbas OAT adalah pemantauan secara intensif fungsi hati pada pasien dengan pemberian INH yang dikombinasi dengan RMP atau PZA. Pentingnya penghentian pengobatan pada pasien yang diduga telah menderita hepatitis imbas OAT. INH, RMP dan PZA merupakan obat lini pertama yang efektif untuk TB, penggunaan kembali obat ini dapat dilakukan ketika fungsi hati telah kembali ke tingkat normal. ${ }^{14}$ Namun, dimulai dari dosis rendah dan selalu memonitoring fungsi hati.

\section{Mekanisme Terjadinya Toksisitas OAT}

Asetilasi INH didapatkan dari pembentukan acetylisoniazid, yang mana selanjutnya, dapat dihidrolisis menjadi asetil hidrazin dan kemudian menjadi nontoxic diacetyl hidrazin oleh NAT2. Jalur alternatif hipotetis lain untuk sintesis asetil hidrazin adalah hidrolisis INH ke hidrazin beracun yang mungkin diasetilasi menjadi (mungkin beracun) monoacetyl hidrazin. Meskipun mekanisme tidak jelas, hidrazin telah terbukti hepatotoksik pada hewan. ${ }^{14}$ Pada suatu penelitian menunjukkan bahwa oksidasi CYP2E1 dimediasi dari monoacetyl hidrazin dapat menghasilkan hepatotoksin seperti acetyldiazene, ion acetylonium, asetil radikal atau ketena (Gambar 1). ${ }^{15}$ hepatotoksin ini dapat didetoksifikasi oleh kehadiran GSTs dalam hati. Secara alternatif, monoacetyl hidrazin juga selanjutnya dapat di asetilasi oleh NAT2 menjadi (mungkin tidak beracun) diacetyl hidrazin. INH juga dihidrolisis oleh isoniazid hidrolase menjadi asam isonikotinat yang dapat dikonjugasi dengan glisin dan diekskresikan oleh ginjal. ${ }^{14}$ RMP adalah inducer kuat dari CYP2E1, sehingga dapat meningkatkan aktivitas enzim ini dan dapat mengatur produksi agen hepatotoksik. Hal ini bisa menjadi salah satu mekanisme yang memungkinkan dimana RMP meningkatkan toksisitas INH. Dikatakan bahwa INH diubah menjadi diacetyl hidrazin secara cepat dalam asetilator cepat dan diekskresikan dari tubuh, sehingga asetilator cepat kurang rentan untuk hepatitis imbas OAT. ${ }^{15}$ Namun, karena lambatnya proses asetilasi, sebagian kecil monoacetyl hidrazin diubah menjadi diacetyl hidrazin di asetilator lambat dan sebagian besar monoacetyl hidrazin dioksidasi menjadi produk beracun oleh CYP2E1. Karenanya asetilator lambat menjadi rentan terhadap hepatitis imbas OAT apabila produk beracun tidak dihilangkan dari hati. Pada NAT2 asetilator lambat, karena hidrolisis, sebagian INH mungkin juga dikonversi ke hidrazin beracun, yang dapat meningkatkan hepatotoksisitas OAT.

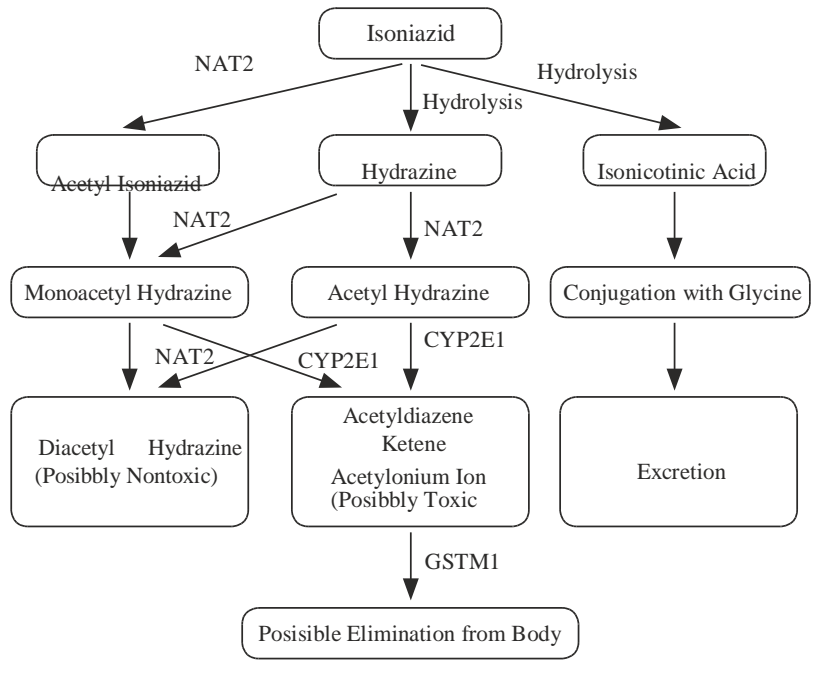

Gambar 1. Kemungkinan jalur metabolisme dari INH oleh NAT2, CYP2E1 dan GSTM1.

\section{Polimorfisme dan Hepatotoksisitas OAT}

Beberapa penelitian mempelajari hubungan antara polimorfisme pada lokus metabolisme obat yang berbeda dan risiko hepatotoksisitas oleh karena OAT pada populasi yang berbeda. Dikatakan bahwa NAT2 asetilator lambat rentan terhadap hepatotoksisitas INH. Saat ini tidak hanya enzim NAT2 saja tetapi beberapa enzim lain (seperti CYP2E1 dan GSTM1) juga terlibat dalam hepatotoksisitas OAT. Pada bagian selanjutnya akan dibahas polimorfisme pada lokus ini, serta asosiasi antara polimorfisme dan risiko hepatotoksisitas OAT.

\section{NAT2 polimorfisme}

Pada manusia, NAT2 mengurangi konsentrasi terapeutik dari INH oleh $\mathrm{N}$-asetilasi. Turunan asetilasi dari INH menghambat sekitar 100 kali lebih sedikit aktifitasnya secara invivo dan 500-kali lebih sedikit aktifitasnya secara invitro terhadap M. tuberculosis. Hal ini menunjukkan bahwa $\mathrm{N}$-asetil transferase dari $\mathrm{M}$. tuberculosis meningkatkan kelangsungan hidup bakteri selama pengobatan INH. Oleh karena itu, asetilasi dari INH oleh bakteri NAT dapat membuat itu tidak aktif. NAT endogen dari M. tuberculosis mungkin memiliki fungsi yang berbeda dalam proses perkembangannya, tetapi dapat mengubah sensitivitas bakteri terhadap INH. ${ }^{16}$ Pada manusia, NAT2 memainkan peran penting dalam menentukan hepatotoksisitas INH, dan beberapa bagian polimorfik telah dilaporkan pada NAT2. Oleh karena itu, sangat penting untuk memahami hubungan antara variasi genetik/polimorfisme pada NAT2 dan kapasitas asetilasi enzim. Lokus NAT2 berisi beberapa single nucleotide polymorphism (SNP) tetapi hanya sedikit yang monomorfik pada populasi etnis yang berbeda. Genotip di beberapa SNP, mungkin diperlukan untuk menentukan status asetilasi yang tepat pada setiap individu dalam suatu 
populasi. ${ }^{19}$ Sekitar $50 \%$ dari individu heterozigot pada dua atau lebih SNP. Sebuah software digunakan untuk mengidentifikasi sepasang alel atau kehadiran haplotype dalam individu dari populasi. ${ }^{18}$ Sebagian besar peneliti mempelajari tujuh atau kurang SNP pada posisi nukleotida (np) (191 [G/A], $282[\mathrm{C} / \mathrm{T}], 341[\mathrm{~T}>\mathrm{C}], 481[\mathrm{C}>\mathrm{T}], 590$ [G > A], $803[\mathrm{~A}>\mathrm{G}]$ dan $857[\mathrm{G}>\mathrm{A}]$ ) pada ekson 2 pada NAT2 lokus untuk menentukan status asetilasi individu dalam studi different association. (Gambar 2) Alel pada SNP dapat ditentukan oleh PCR-fragmen restriksi length polymorphism (RFLP) dan sebaliknya menganalisis data genotipe di situs polimorfik secara terpisah, genotipe umumnya dinyatakan sebagai alel/ haplotype, seperti NAT2 $* 4$, NAT2 $* 5$, NAT2 $* 6$, NAT2 $* 7$, NAT2 $* 12$ dan seterusnya, tergantung pada pengaturan nukleotida (G/A, C/T , T/C , C/T , G/A , A/G dan G/A pada 191, 282, 341, 481, 590, 803, dan 857np masing-masing) sesuai yang disebutkan pada situs polimorfik diatas. Sebuah software (disebut FASE v2.1.1, program statistik untuk rekonstruksi haplotype) digunakan untuk menentukan pasangan haplotype pada setiap individu dari data genotipe. ${ }^{19}$ Beberapa dari SNP (seperti 341np T > C, 481np C > T dan 803np A > G) berada dalam hubungan disequilibrium yang kuat, ${ }^{18}$ sehingga genotipe pada SNP $341 \mathrm{np} \mathrm{T}>$ $C$ dapat memberikan informasi alel dua SNP lainnya (481np C > T dan 803np A > G). Beberapa SNP memiliki frekuensi yang kurang atau monomorfik di populasi yang berbeda, seperti 191np G/A pada populasi India. Pada alel yang umum (yaitu, NAT2 * 4) yang memiliki kesamaan nukleotida di semua situs polimorfik yang dikenal sebagai NAT2 alel acetylating cepat. Polimorfisme pada 481 dan 803 np tidak dapat mengubah status asetilasi, tetapi varian alel/haplotipe ${ }^{17}$ memiliki setidaknya satu varian nukleotida pada salah satu dari situs polimorfik pada 341, 590 dan 857np yang dikenal sebagai alel acetylating lambat (misalnya, NAT2 $* 5, \mathrm{NAT} 2 * 6 \mathrm{~B}$ dan NAT2 $* 7 \mathrm{~A}$ ).

Oleh karena itu, individu membawa dua alel acetylating cepat (seperti NAT2 $*$ 4/NAT2 $* 4$ genotipe) di sepasang kromosom adalah asetilator cepat; membawa dua alel acetylating lambat (seperti NAT2 $* 5 / \mathrm{NAT} 2 * 6 \mathrm{~B}$ genotipe) merupakan asetilator lambat; dan mereka membawa acetylating alel satu lambat dan satu cepat (yaitu, NAT2 * 4/NAT2 * 5 genotipe) yang merupakan asetilator intermediate.

Dengan menggunakan data haplotype, peneliti melaporkan bahwa frekuensi NAT2 asetilator cepat, intermediate dan lambat sama pada ras Kaukasia dan populasi di India. ${ }^{18}$ Frekuensi dari NAT2 asetilator cepat, intermediate dan lambat juga mirip pada populasi di Jepang dan Cina. ${ }^{18}$ Oleh karena itu, bisa dicatat bahwa NAT2 asetilator lambat lebih sering ditemukan pada populasi Kaukasia dan India, sedangkan jarang pada populasi di Jepang dan Cina (Tabel 1). Studi pada populasi di Jepang dan Taiwan menggunakan metode genotip PCRRFLP, di pnI (481np C > T), TaqI (590np G > A) dan BamHI (857np G > A) situs polimorfik, untuk menemukan Status asetilasi pasien dan kontrol, dan mengesankan risiko tinggi hepatotoksisitas OAT, dengan RR 28,0 dan CI 95\% dari 26-30 dan OR dari 3.66; 95\% CI 1,58-8,49 dari, masingmasing, di NAT2 asetilator lambat. ${ }^{20}$ Baru-baru ini, sebuah studi pada populasi Korea juga mengamati bahwa NAT2 asetilator lambat memiliki risiko yang signifikan dari hepatotoksisitas oleh karena OAT (Risiko 3,8 kali lipat, $\mathrm{p}=0,005)$. Kami menggenotipkan pada MspI, KPNI dan BamHI situs polimorfik penduduk India, dan Vuilleumier et al. ${ }^{20}$ dan menggenotipkan pada $191 \mathrm{np}$, KPNI, TaqI dan BamHI situs polimorfik dalam campuran populasi Kaukasia, Hispanik, Afrika, Amerika Selatan dan Asia. Namun, dua studi ini tidak bisa menunjukkan hubungan antara hepatotoksisitas OAT dan status asetilasi NAT2. Semua studi yang disebutkan di atas dianggap bahwa hilangnya situs KpnI di 481np akan menyebabkan asetilasi lambat. Tapi telah dilaporkan bahwa hilangnya situs KPNI di 481np tidak mengubah status asetilasi dalam uji fenotipik. ${ }^{17}$ Oleh karena itu, pengamatan yang disebutkan di atas harus divalidasi oleh genotip setidaknya satu lebih SNP, (katakanlah $341 \mathrm{~T}>\mathrm{C}$ ) meskipun C481T (Situs KPNI) polimorfisme sangat terkait dengan polimorfisme T341C dalam populasi India yang mengarah untuk memperlambat asetilasi (Das Roy P et al). ${ }^{18}$ Oleh karena itu, penting untuk mengetahui status linkage disequilibrium pada populasi antara C481T dan T341C, jika polimorfisme pada $481 n$ p digunakan untuk menentukan status asetilasi dari individual. Namun, harus dilakukan untuk memilih SNP sesuai untuk genotip dan mengklasifikasikan individu sebagai asetilator lambat, cepat atau intermediate, jika tidak terlalu tinggi asetilator lambat dapat diperoleh. Hal ini mungkin menjadi sumber kesalahan dalam studi. Namun, studi dengan ukuran sampel yang lebih besar dari populasi yang berbeda dan genotip pada situs polimorfik yang tepat adalah sangat penting dalam memperoleh pemahaman yang jelas dari hubungan antara status asetilasi NAT2 dan hepatotoksisitas OAT.

\section{CYP2E1 Polimorfisme}

CYP merupakan kelompok besar multigen dengan spesifisitas substrat yang berbeda, sangat penting dalam reaksi oksidasi beberapa bahan kimia eksogen dan endogen ke bentuk reaktif utama mereka. CYP2E1, salah satu Enzim CYP, dapat mengkonversi asetil hidrazin menjadi hepatotoksin, seperti acetyldiazene, ketena, ion acetylonium dan sebagainya, yang dapat mempengaruhi hepatotoksisitas OAT. (Gambar 1). INH atau metabolit hidrazin dapat menginduksi aktivitas CYP2E1 pada tikus, tergantung pada dosis INH dalam darah. Namun, INH juga bisa menghambat Aktivitas CYP2E1, dan inhibisi ini lebih banyak terdapat pada manusia dengan varian genotipe pada CYP2E1. Oleh karena itu, individu dengan genotipe umum di CYP2E1 mungkin memiliki aktivitas lebih tinggi CYP2E1 dibandingkan dengan individu dengan varian genotipe di CYP2E1 ketika diobati dengan INH. Aktivitas yang lebih tinggi dari CYP2E1 mungkin meningkatkan sintesis hepatotoksin dan meningkatkan risiko hepatotoksisitas. $^{21}$ 
Tabel 1. Distribusi dari status asetilasi, genotipe dan alel pada populasi yang berbeda. ${ }^{20}$

\begin{tabular}{|c|c|c|c|c|c|}
\hline & & \multicolumn{4}{|c|}{ Acetylation Frequency (\%) } \\
\hline Locus & Population & Fast/Rapid & Intermediate & Slow & \\
\hline \multirow[t]{6}{*}{ NAT2 } & Caucasian & 6 & 37 & 57 & \\
\hline & Indian & 4 & 36 & 60 & \\
\hline & Japanese & 48 & 46 & 6 & \\
\hline & Chinese & 35 & 47 & 18 & \\
\hline & & \multicolumn{4}{|c|}{ Genotype/allele Frequency (\%) } \\
\hline & & $* 1 \mathrm{~A} / * 1 \mathrm{~A}$ & $* 1 \mathrm{~A} / * 5$ & $* 5 * 5$ & $* 6$ allele \\
\hline \multirow[t]{6}{*}{ CYP2E1 } & European-American & 92 & 7 & 1 & 10 \\
\hline & African-American & 98 & 2 & 0 & - \\
\hline & Taiwanese & 56 & 32 & 12 & 25 \\
\hline & Japanese & - & 26 & - & 33 \\
\hline & Hawaiians & - & 16 & - & 15 \\
\hline & Indian & 98 & 2 & 0 & 20 \\
\hline
\end{tabular}

Aktivitas CYP2E1 juga dipengaruhi oleh adanya lokus polimorfisme di beberapa situs. Dua polimorfisme hulu dari CYP2E1 transkripsi situs awal ini terdeteksi oleh PstI dan RsaI enzim restriksi dan menjadi linkage disequilibrium secara lengkap (Gambar 2). ${ }^{21}$ Berdasarkan nilai positif [+] atau negatif [-] dari urutan RsaI dan PstI, haplotype umum (RsaI [+]. PstI [-]), Dan salah satu varian haplotype, (RsaI [-]. PstI [+]), yang ditunjuk sebagai 'c1' dan 'c2' alel, masing-masing. Saat ini, c1 liar ini haplotype telah ditandai sebagai CYP2E1 * 1A, dan haplotype varian c2 telah diubah namanya sebagai CYP2E1 $* 5$ alel. PstI dan RsaI situs polimorfik tersedia dalam Situs HNF-1 mengikat, dan dengan demikian dapat memainkan penting peran dalam regulasi transkripsi CYP2E1 dan ekspresi protein berikutnya. DraI polimorfisme pada intron 6 dari CYP2E1 mengarah ke varian CYP2E1 * 6 alel (tidak adanya situs restriksi DraI). Polimorfisme lain (96 bp penyisipan/delesi CYP2E1 * 1D / * 1C polimorfisme) pada 5'-bagian regulasi dari gen ini juga bisa mengatur aktivitas enzim. Beberapa penelitian melaporkan bahwa varian CYP2E1 $* 5$, * 6 dan * 1D alel berhubungan dengan peningkatan aktfitas enzim. Namun, peneliti lain tidak dapat mengkonfirmasi hubungan ini. Frekuensi alel CYP2E1 * 6 adalah 10\%, 25\%, 33\%, $15 \%$ dan $20 \%$ di Eropa-Amerika, Taiwan, Jepang, Hawaii dan India populasi masing-masing. Frekuensi CYP2E1 * $1 \mathrm{~A} / * 1 \mathrm{~A}, 1 \mathrm{~A} * / * 5$ dan $* 5 / 5 *$ genotipe telah dilaporkan dalam populasi yang berbeda (Tabel 1). Mereka serupa pada populasi Eropa-Amerika, Afrika-Amerika dan India, tetapi bervariasi pada orang-orang di populasi Taiwan. Sebuah laporan pasien Taiwan telah menunjukkan bahwa sangat umum * 1A / * 1A genotipe di CYP2E1 meningkatkan risiko hepatotoksisitas OAT, dengan OR 2,52 dan 95\% CI dari 1,26-5,05, pada pasien TB dewasa. Penelitian yang sama juga melaporkan bahwa individu dengan genotipe * 1A / * 1A dan NAT2 dengan status asetilasi lambat telah meningkatkan risiko hepatotoksisitas OAT, dengan OR 7,43 dan 95\% CI dari 2,42-22,79, dibandingkan dengan $* 1 \mathrm{~A} / * 1 \mathrm{~A}$ genotipe (OR: $2,52,95 \%$ CI: $1,26-5,05)$ atau status asetilasi lambat saja (OR: 2,3, 95\% CI: 1,21-4,39). Meskipun ukuran sampel rendah, juga diamati bahwa CYP2E1 varian * 6 alel dan *1A-* 6 - * 1D haplotype pada CYP2E1 meningkatkan risiko hepatotoksisitas (OR: 11,0; 95\% CI: 1,02-110 dan OR: 4,6; 95\% CI: 1,3-16,3) pada pasien anak-anak di India. ${ }^{21}$ Haplotype ini * $1 \mathrm{~A}-*$ 6 - * 1D termasuk umum *1A alel pada situs (RsaI [+]. PstI [-]), tetapi varian * 6 dan * 1D alel ada pada dua situs polimorfik lainnya. Studi lain pada populasi campuran Kaukasia, Hispanik, Afrika, Amerika Selatan dan Asia juga mengamati bahwa * 1A alel umum pada CYP2E1 meningkatkan enzim hati oleh karena OAT. Namun sebuah studi Korea tidak mengamati hubungan antara hepatotoksisitas OAT dan CYP2E1 polimorfisme. ${ }^{20}$

\section{GSTM1 \& GSTT1 polimorfisme}

GSTs adalah keluarga enzim yang dikenal memainkan peran penting dalam detoksifikasi beberapa karsinogen, bahan kimia beracun dan obat-obatan. GSTs umumnya mengkatalisis konjugasi reaksi antara glutathione dan substrat untuk solubilisasi dan ekskresi dari tubuh. Enzim ini dikodekan oleh setidaknya lima lokus yang berbeda, yang dikenal sebagai $\alpha, \mu, \pi, \Phi$ dan $\mathrm{y}$. dari jumlah tersebut lima lokus, GSTM1 (tipe $\mu$ ) dan GSTT1 (tipe $\Phi$ ) mendapatkan perhatian dalam hepatotoksisitas. Delesi homozigot di GSTM1 dan GSTT1 pada beberapa individu mengakibatkan hilangnya aktivitas enzimatik, tetapi individu yang membawa salah satu atau kedua alel fungsional memiliki aktivitas enzimatik. Polimorfisme pada dua lokus ini telah dipelajari secara ekstensif dalam populasi yang berbeda. Frekuensi dari GSTM1 dan GSTT1 delesi homozigot genotipe pada individu yang sehat dilaporkan pada populasi yang berbeda (Tabel 2). Secara umum, frekuensi delesi homozigot relatif lebih besar di Kepulauan Pasifik, Malaysia, Populasi Cina, Korea dan Jepang. Sedikit populasi etnis di India juga memiliki tinggi frekuensi GSTM1 dan GSTT1 delesi homozigot genotipe. $^{20,21}$ 
Glutathione S-transferase memainkan peran penting pada metabolisme OAT, terutama INH. Hepatotoksisitas INH terbukti berhubungan dengan pengurangan kandungan glutathione hati dan penurunan aktivitas GST. Glutathione (GSH) memainkan peran sebagai pelindung intraseluler scavenger radikal bebas konjugasi dengan metabolit toksik yang dihasilkan dari metabolisme INH. Sulfhidril (SH) konjugasi memiliki peran pengeluaran dari tubuh dan mengurangi potensi toksisitas. Kekurangan aktivitas GST, karena delesi homozigot di lokus GSTM1 dan GSTT1, dapat memodulasi kerentanan untuk terjadinya hepatotoksisitas. Risiko hepatotoksisitas OAT meningkat, dengan OR 2,13 dan CI 95\% dari 1,25-3,10, pada pasien India dengan delesi GSTM1 homozigot. Demikian pula, Huang et al. juga melaporkan bahwa pasien dengan delesi GSTM1 homozigot memiliki risiko tinggi INH-induced hepatotoksisitas, dengan OR: 2,23; 95\% CI: 1,07-4,67, pada populasi di Taiwan. Oleh karena itu, skrining pada pasien dengan delesi GSTM1 homozigot dapat memberikan informasi yang lebih baik untuk mengontrol kerusahan organ hati. ${ }^{20,21}$

\section{KESIMPULAN}

Hepatotoksisitas oleh karena OAT adalah masalah medis serius di dunia terutama untuk pasien TB. Telah dipelajari hubungan antara hepatotoksisitas OAT dan polimorfisme pada berbagai metabolisme obat dalam populasi yang berbeda di seluruh dunia. Beberapa penelitian melaporkan bahwa NAT2 asetilasi lambat dan alel CYP2E1 * IA meningkatkan risiko hepatotoksisitas OAT. Selain itu, delesi GSTM1 homozigot bisa meningkatkan risiko hepatotoksisitas.

\section{DAFTAR PUSTAKA}

1. Farrell GC: Drug-induced acute hepatitis. In: Drug-induced liver disease Farrell GG (Ed.). Churchill Livingstone, Edinburgh, UK.1994; 247-299.

2. Pessayre D, Larrey D: Drug-induced liver injury: In: Oxford Textbook of clinical Hepatology. Volume 2. (Eds). Oxford University Press, Oxford, UK. 1991.

3. Sim E, Payton M, Noble M, Minchin R: An update on genetic, structural and functional studies on arylamine $\mathrm{N}$-acetyltransferases in eucaryotes and procaryotes. Hum. Mol. Genet.2000; 9: 2435-2441.
4. Nebert DW: Polymorphism in drug-metabolizing enzymes: what is their clinical relevance and why do they exist. Am. J. Hum. Genet. 1997; 60: 265-271.

5. Yamamoto T, Suou T, Hirayama C: Elevated serum aminotransferase induced by isoniazid in relation to isoniazid acetylator phenotype. Hepatology 1986: 6; 295-298.

6. Benichou C: Criteria of drug induced liver disorder: report of an International Consensus Meeting. J. Hepatol. 1990: 11; 272-276.

7. Larrey D. Epidemiology and individual susceptibility to adverse drug reactions aff ecting the liver. Semin Liver Dis. 2002; 22; 145-55.

8. Navarro VJ, Senior JR. Drug-related hepatotoxicity. N Engl J Med. 2006; 354: 731-9.

9. Rapp RS, Campbell RW, Howell JC, Kendig ELJ: Isoniazid hepatotoxicity in children. Am. Rev. Respir. Dis. 1978: 118; 794796.

10. Pande JN, Singh SPN, Khilnani GC, Khilnani S, Tandon RK: Risk Factors for hepatotoxicity from antituberculous drugs: a case control study. Thorax 1996: 51; 132-136.

11. Girling DJ: The hepatic toxicity of antituberculosis regimens containing isoniazid, rifampicin and pyrazinamide. Tubercle. 1978: 59; $13-32$.

12. Fountain FF, Tolley E, Chrisman CR, Self TH: Isoniazid hepatotoxicity associated with treatment of latent tuberculosis infection: a 7-year evaluation from a public health tuberculosis clinic. Chest. 2005: 128; 116-123.

13. Saukkonen JJ, Cohn DL, Jasmer RM et al.: An official ATS statement: hepatotoxicity of antituberculosis therapy. Am. J. Respir. Crit. Care Med. 2006: 174; 935-952.

14. Garg PK, Tandon RK: Antituberculous Agents Induced Liver Injury. In: Drug-induced Liver Disease. Kaplowitz N, Deleve LD (Eds). Marcel Dekker, New York, USA. 2003.

15. Sarma GR, Immanuel, C, Kailasam S, Narayana AS, Venkatesan P: Rifampicininduced release of hydrazine from isoniazid. A possible cause of hepatitis during treatment of tuberculosis with regimens containing isoniazid and rifampicin. Am. Rev. Respir. Dis. 1986: 133; 1072-1075.

16. Upton AM, Mushtaq A, Victor TC et al.: Arylamine N-acetyltransferase of Mycobacterium tuberculosis is a polymorphic enzyme and a site of isoniazid metabolism. Mol. Microbiol. 2001: 42; 309-317.

17. Description of different alleles at NAT2 and corresponding acetylating status www.louisville.edu/medschool/pharmacology/nat.html

18. Golka K, Blaszkewicz M, Samimi M, Bolt HM, Selinski S: Reconstruction of $\mathrm{N}$-acetyltransferase 2 haplotypes using PHASE. Arch. Toxicol. (2007) (Epub ahead of print).

19. A software to restructure the haplotypes from genotype data www. stat.washington.edu/stephens/

20. Cho HJ, Koh WJ, Ryu YJ et al.: Genetic polymorphisms of NAT2 and CYP2E1 associated with antituberculosis drug-induced hepatotoxicity in Korean patients with pulmonary tuberculosis. Tuberculosis (Edinb.) 2007: 87; (6), 551-556.

21. Huang YS, Chern HD, Su WJ et al.: Cytochrome P450 2 E1 genotype and the susceptibility to antituberculosis druginduced hepatitis. Hepatology. 2003: 37; 924-930. 